\title{
The use of digitalization for micro, small and medium enterprises
}

\author{
By : Dika Anggara Putra
}

NRP : 130119046

As we know, the Indonesian economy experienced a deflation of $0.1 \%$ in July 2020. This occurred in the food, beverage and tobacco category, which experienced a deflation of $0.79 \%$ and contributed $0.19 \%$ to deflation. Foodstuffs that contributed to deflation included shallots, free-range chicken, rice, garlic, cayenne pepper, and sugar. Deflation in July and August 2020 was triggered more by falling prices for a number of food, beverage and transportation groups, indicating large demand amid the Covid-19 pandemic. Trends in other countries indicate a slowdown in inflation and deflation hitting supply and demand. in 4 countries such as Indonesia, the Philippines, Thailand and Laos involving 3,831 MSME respondents explained that the contribution of MSMEs to Gross Domestic Product in these 4 countries was more than 50\%. The implementation of regional restrictions has a negative impact on MSMEs, but some MSMEs continue to operate despite experiencing a decline in income of more than $40 \%$.

The recovery of MSMEs cannot be separated from the use of information technology, considering that digitalization is the key for entrepreneurs to survive and thrive in the midst of the Covid-19 pandemic. still relatively small. This means that solutions and innovations are urgently needed for the digitization of MSMEs. Unfortunately, the process of digitizing MSMEs cannot happen immediately. It is best to join an e-commerce provider, such as Shopee, Tokopedia, and Bukalapak. Efforts to digitize MSMEs need to be maintained in various ways, including consistent and routine assistance by e-commerce companies. Therefore, the government conducts ultra-micro financing based on digital technology intended to accelerate financial penetration and inclusion, considering that ultra-micro business actors still have difficulty accessing bank financing due to various factors, such as not having a bank account, hard-to-reach locations, or very large business scale. small.

Experts say that small traders are business actors with relatively small capital who carry out production activities or sell goods and services to meet the needs of certain groups in society. This business activity is usually carried out in strategic places informally, such as roadsides, parks and riverbanks. In terms of business development, small traders such as warungs, street vendors or hawkers, and small shops are micro businesses that operate informally. Based on the current developing conditions, the government must focus more on controlling the Covid-19 pandemic so that confirmed 
cases can be reduced, small businesses must be one of the government's priorities when carrying out transformation by rearranging the national economy in an effort to encourage economic growth, prevent recession and the Covid pandemic crisis. -19, and significantly reduce unemployment and poverty. Ultra micro businesses are the lowest strata in micro and small businesses that are carried out by only one or two people with a capital of IDR 1 million-Rp 2 million, and are classified as low-income or poor people. This group includes hawkers, street vendors, small stalls, market traders, and food stalls with daily income.

The use of digital financial services has the opportunity to encourage the internet economy and is expected to support the financing of the productive sector. However, the biggest problem in financing the productive sector is the low productivity of ultra-micro scale businesses. This means that business actors are expected to be able to use the internet to increase productivity, increase the number of products, and increase the variety of businesses. Ideally, economic achievements through the internet are not only seen from the providers of trading platforms, because the biggest influence is felt by micro, small and medium entrepreneurs themselves. Ultra-micro financing based on digital technology is aimed at accelerating penetration and financial inclusion, considering that ultra-micro business actors still have difficulty accessing bank financing due to various factors, such as not having a bank account, hard-to-reach locations. reach, or very small scale of business. Because of their strategic role in development, MSMEs must continue to be developed.

Therefore, every micro, small and medium entrepreneur is required to be able to personalize their digital tools and open up to the community they need. The business

platforms that are currently developing are no longer based on physical assets and natural resources, but on collaborative functions assisted by technology, such as Bukalapak, Blibli, Tokopedia, Shopee, Traveloka, and Lazada, including financial technology startups.

\section{References}

Tayibnapis, A. Z., Wuryaningsih, L. E., \& Gora, R. (2021). South Asian Journal of Social Studies and Economics. Medium, Small and Medium Enterprises and Digital Platforms, 10(2), 1019. doi:10.9734/SAJSSE/2021/v10i230258 